\title{
Taxonomic studies on the genus Cystofilobasidium: description of Cystofilobasidium ferigula sp. nov. and clarification of the status of Cystofilobasidium lari-marini
}

\author{
José Paulo Sampaio, ${ }^{1}$ Mário Gadanho ${ }^{1}$ and Robert Bauer ${ }^{2}$
} Author for correspondence: José Paulo Sampaio. Tel: +35121 2948300. Fax: +351212948530.
e-mail: jss@mail.fct.unl.pt

\footnotetext{
${ }^{1}$ Centro de Recursos Microbiológicos, Secção Autónoma de Biotecnologia, Faculdade de Ciências e Tecnologia, Universidade Nova de Lisboa, 2825-114 Caparica, Portugal

2 Universität Tübingen, Institut für Biologie I, Lehrstuhl Spezielle Botanik und Mykologie, Auf der Morgenstelle, 1, D-72076 Tübingen, Germany
}

\begin{abstract}
A new species of the genus Cystofilobasidium is described as Cystofilobasidium ferigula sp. nov. The new taxon represents the teleomorphic stage of Cryptococcus ferigula and was obtained in mating experiments using three strains deposited in the Portuguese Yeast Culture Collection (mating types A1) and a recent isolate (mating type A2). Cystofilobasidium ferigula is characterized using an integrated approach encompassing morphological studies, investigation of the ultrastructure of the septal pore, a comparative study of physiological traits, determination of the DNA base composition, DNA reassociation experiments and PCR fingerprinting. During the course of this study, a close similarity of microsatellite-primed PCR fingerprints was detected between Cystofilobasidium lari-marini and Cystofilobasidium capitatum. DNA-DNA reassociation experiments gave high homology values, which indicates that Cystofilobasidium lari-marini must be regarded as a synonym of Cystofilobasidium capitatum.
\end{abstract}

Keywords: heterobasidiomycetes, basidiomycetous yeasts, systematics, Cystofilobasidiales, Cystofilobasidium ferigula sp. nov.

\section{INTRODUCTION}

The heterobasidiomycetous genus Cystofilobasidium Oberwinkler et Bandoni (Oberwinkler et al., 1983) was created to accommodate two teliospore-producing yeasts previously classified in Rhodosporidium Banno, namely Cystofilobasidium bisporidii (Fell, Hunter et Tallman) Oberwinkler et Bandoni and Cystofilobasidium capitatum (Fell, Hunter et Tallman) Oberwinkler et Bandoni. Members of the genus Cystofilobasidium produce Filobasidium-like basidia, i.e. holobasidia each having a narrow central region and a swollen apex (Oberwinkler et al., 1983), whereas in Rhodosporidium the basidia are tubular and transversely septate. At present, the genus Cystofilobasidium includes four species: three are pink-coloured and one is cream-coloured. The pigmented species are the two mentioned above and Cystofilobasidium infirmo-

Abbreviation: CMA, corn meal agar; UPGMA, unweighted pair group method using arithmetic averages. miniatum (Fell, Hunter et Tallman) Hamamoto, Sugiyama et Komagata (Hamamoto et al., 1988), also transferred from Rhodosporidium. More recently, Cystofilobasidium lari-marini (Saëz et Nguyen) Fell et Statzell-Tallman (cream-coloured) was transferred from Leucosporidium Fell, Statzell, Hunter et Phaff (Fell \& Statzell-Tallman, 1992).

The order Cystofilobasidiales (Fell et al., 1999) was proposed on the basis of studies of 26S rDNA sequences. This order includes two teleomorphic genera, Cystofilobasidium and Mrakia Yamada et Komagata, the anamorphic genus Udeniomyces Nakase et Takematsu and three species of Cryptococcus Vuillemin, viz. Cryptococcus aquaticus (Jones et Slooff) Rodrigues de Miranda et Weijman, Cryptococcus ferigula (corrig.) Saëz et Rodrigues de Miranda and Cryptococcus macerans (Frederiksen) Phaff et Fell. According to Fell et al. (1999), the Cystofilobasidiales clade includes two subclades, the Mrakia subclade and the Cystofilobasidium subclade. The latter group includes all known species of Cystofilobasidium and also Cryptococcus ferigula and Cryptococcus macerans. 
Cryptococcus ferigula is a pink yeast originally found in the oral cavity of several wild animals kept in captivity (Saëz \& Rodrigues de Miranda, 1988). This report presents the description of the sexual state of Cryptococcus ferigula and the consequent proposal of a new species of the genus Cystofilobasidium. Our studies also revealed that $C y$ stofilobasidium lari-marini should be considered as a synonym of Cystofilobasidium capitatum.

\section{METHODS}

Yeast cultures. The list of strains used in this study, and relevant information, is shown in Table 1.

Morphological and physiological characterization. Physiological and biochemical characterization was performed according to the techniques described by Yarrow (1998). Additional assimilation tests were performed using aldaric acids and aromatic compounds as described by Fonseca (1992) and Sampaio (1994), respectively. All assimilation tests were performed twice, in separate experiments. The results of the 78 tests selected by Sampaio \& Fonseca (1995) were used to calculate the overall similarity of physiological and biochemical profiles, employing numerical taxonomy methods (the data matrix is available upon request). The similarity between strains was estimated using the simple- matching coefficient and cluster analysis was performed using the UPGMA (unweighted pair-group method using arithmetic averages) algorithm (Sneath \& Sokal, 1973). These analyses were computed using the NTSYs-pc software package, version 2.0 (Rolf, 1998). For microscopy, cultures were grown at room temperature on YM agar (Yarrow, 1998) or on corn meal agar (CMA) and studied with phasecontrast optics.

Ultrastructure. For transmission electron microscopy, samples were fixed overnight in $2 \%$ glutaraldehyde in $0 \cdot 1 \mathrm{M}$ sodium cacodylate buffer at $\mathrm{pH} 7 \cdot 2$. After six transfers in $0 \cdot 1 \mathrm{M}$ sodium cacodylate buffer, the material was post-fixed in $1 \%$ osmium tetroxide in the same buffer for $2 \mathrm{~h}$ in the dark, washed in distilled water and stained in $1 \%$ aqueous uranyl acetate for $1 \mathrm{~h}$ in the dark. After five washes in distilled water, samples were dehydrated in acetone, using 10 min changes at 25, 50, 70 and $95 \%(\mathrm{v} / \mathrm{v})$, and three times in $100 \%$ acetone. The material was embedded in Spurr's plastic (Spurr, 1969). Serial sections $(65-75 \mathrm{~nm})$ were cut with a Reichert-Jung Ultracut E (Leica) equipped with a diamond knife. Sections were mounted on Formvar-coated, single-slot, copper grids, stained with lead citrate (Reynolds, 1963) at room temperature for 3-5 min and washed again with water. The thin sections were examined at $80 \mathrm{kV}$ with a Zeiss EM 109 transmission electron microscope.

Determination of DNA base composition and DNA reassociation experiments. For DNA isolation, strains were

Table 1. List of strains studied in this work

Culture collections are abbreviated as: IGC, Portuguese Yeast Culture Collection, FCT-UNL, Caparica, Portugal; CBS, Centraalbureau voor Schimmelcultures, Yeast Division, Delft, The Netherlands; FO, personal collection of F. Oberwinkler, University of Tübingen, Germany; ZP, personal collection of J. P. Sampaio.

\begin{tabular}{|c|c|c|c|c|}
\hline Species & Strain & Strain origin & Isolation source & Observations \\
\hline Cryptococcus macerans & IGC $2869^{\mathrm{T}}$ & CBS $2206^{\mathrm{T}}$ & Dew-retted flax straw, Denmark & \\
\hline Cryptococcus macerans & IGC 4482 & & Flower of Cineraria sp., Oeiras, Portugal & \\
\hline Cryptococcus macerans & IGC 4737 & & Grasshopper, Sintra, Portugal & \\
\hline Cystofilobasidium bisporidii & IGC $4415^{\mathrm{T}}$ & CBS $6346^{\mathrm{T}}$ & Seawater, Antarctic Ocean & Mating type A1B1 \\
\hline Cystofilobasidium capitatum & IGC $4418^{\mathrm{T}}$ & CBS $6358^{T}$ & Zooplankton, Antarctic Ocean & Self-sporulating \\
\hline Cystofilobasidium capitatum & IGC 4309 & FO 31572.a & $\begin{array}{l}\text { Gleba of Phallus impudicus, Tübingen, } \\
\text { Germany }\end{array}$ & Self-sporulating \\
\hline Cystofilobasidium capitatum & IGC 5626 & ZP 317 & $\begin{array}{l}\text { Trifolium sp. leaf infected with rust, } \\
\text { Sesimbra, Portugal }\end{array}$ & Self-sporulating \\
\hline Cystofilobasidium capitatum & IGC 5627 & ZP 327 & $\begin{array}{l}\text { Contaminant of MYP agar plate, } \\
\text { Caparica, Portugal }\end{array}$ & Self-sporulating \\
\hline Cystofilobasidium ferigula & IGC $5359^{\mathrm{T}}$ & CBS $7202^{\mathrm{T}}$ & $\begin{array}{l}\text { Dead male Papio papio (baboon), } \\
\text { Paris Zoological Gardens, France }\end{array}$ & Mating type A1 \\
\hline Cystofilobasidium ferigula & IGC 4410 & CBS 7201 & $\begin{array}{l}\text { Rhea americana (rhea), Paris Zoological } \\
\text { Gardens, France }\end{array}$ & Mating type A1 \\
\hline Cystofilobasidium ferigula & IGC 4410-I & & - & $\begin{array}{l}\text { Colourless variant } \\
\text { of IGC } 4410\end{array}$ \\
\hline Cystofilobasidium ferigula & IGC 5540 & CBS 6954 & Sawdust (locality of isolation unknown) & Mating type A1 \\
\hline Cystofilobasidium ferigula & IGC 5628 & ZP 322 & $\begin{array}{l}\text { Contamination of home-made sauerkraut, } \\
\text { Caparica, Portugal }\end{array}$ & Mating type A2 \\
\hline Cystofilobasidium infirmominiatum & IGC $3955^{\mathrm{T}}$ & CBS $323^{\mathrm{T}}$ & Air, Japan & Mating type A1 \\
\hline Cystofilobasidium infirmominiatum & IGC 4414 & CBS 2204 & Deep-frozen vegetables, The Netherlands & Mating type A2 \\
\hline Cystofilobasidium lari-marini & IGC $4530^{\mathrm{T}}$ & CBS $7420^{\mathrm{T}}$ & $\begin{array}{l}\text { Larus marinus (Great black-backed gull), } \\
\text { France }\end{array}$ & Self-sporulating \\
\hline
\end{tabular}


Table 2. Physiological characterization of strains of Cystofilobasidium ferigula

Growth is scored as: + , positive; - , negative; D, delayed; w, weak. All four strains gave positive results for utilization of the following compounds: D-glucose, L-sorbose, L-arabinose, L-rhamnose, cellobiose, salicin, arbutin, D-mannitol, inositol, glucono- $\delta$ lactone, 2-keto-D-gluconic acid, D-gluconic acid, D-glucuronic acid, saccharic acid and ethanol. All four strains gave negative results for utilization of the following compounds: D-galactose, D-glucosamine, sucrose, maltose, methyl $\alpha$-D-glucoside, melibiose, lactose, raffinose, melezitose, inulin, soluble starch, erythritol, galactitol, DL-lactic acid, succinic acid, L-tartaric acid, D-tartaric acid, $m$-tartaric acid, mucic acid, methanol, vanillyl alcohol, veratryl alcohol, vanillic acid, veratric acid, ferulic acid, syringic acid, sinapic acid, cinnamic acid, benzoic acid, $p$-hydroxybenzoic acid, $m$-hydroxybenzoic acid, protocatechuic acid, catechol, gallic acid, salicylic acid, gentisic acid, $p$-coumaric acid, caffeic acid, phenol and guaiacol. All four strains gave the same results for the following nitrogen compounds (responses are in parentheses): potassium nitrate $(+)$, sodium nitrite $(+)$, ethylamine $(-)$, L-lysine (D), cadaverine $(-)$, creatine $(-)$, creatinine $(-)$ and D-glucosamine $(-)$. All four strains gave the same results for the following additional tests (responses are in parentheses): growth in vitamin-free medium $(-)$, growth with $0 \cdot 1 \%$ cycloheximide $(-)$, growth at $30^{\circ} \mathrm{C}(+)$, growth at $35^{\circ} \mathrm{C}(-)$, formation of starch-like compounds $(+)$, splitting of arbutin $(+)$, hydrolysis of urea $(+)$ and the colour reaction with diazonium blue $\mathrm{B}(+)$.

\begin{tabular}{|c|c|c|c|c|}
\hline Characteristic & IGC $5359^{\mathrm{T}}$ & IGC 4410 & IGC 5540 & IGC 5628 \\
\hline \multicolumn{5}{|l|}{ Utilization of: } \\
\hline D-Ribose & DW & DW & - & DW \\
\hline D-Xylose & + & $\mathrm{D}$ & $\mathrm{D}$ & + \\
\hline D-Arabinose & + & + & - & - \\
\hline$\alpha, \alpha$-Trehalose & + & DW & DW & + \\
\hline Glycerol & - &,$- \mathrm{DW}$ & - & - \\
\hline Ribitol & - & - & - &,$- \mathrm{D}$ \\
\hline Xylitol & - & - & - &,$- \mathrm{DW}$ \\
\hline D-Glucitol & + & $\mathrm{D}$ & $\mathrm{D}$ & + \\
\hline Citric acid & DW & - & $\mathrm{D}$ & $\mathrm{D}$ \\
\hline L-Malic acid & - &,-+ & - & - \\
\hline Growth with $0.01 \%$ cycloheximide & - & - & - & $\mathrm{D}$ \\
\hline
\end{tabular}

grown for 3-4 d at $22^{\circ} \mathrm{C}$ in shaken YM broth (initial $\mathrm{pH} 8$ ). Cells were ruptured using a hydraulic cell press and the DNA was purified using the method of Britten et al. (1970). The nuclear DNA base composition was determined by following the method of Marmur \& Doty (1962) with a Gilford Response UV-VIS spectrophotometer and its Thermal Programming software with nDNA from Candida parapsilosis (Ashford) Langeron et Talice IGC $2545^{\mathrm{T}}$ (= CBS 604 $\left.{ }^{\mathrm{T}}\right)(\mathrm{G}+\mathrm{C}$ content $=40 \cdot 2 \mathrm{~mol} \%)$ as a reference. For DNA-DNA reassociation experiments, the same instrument was used and the methods of Seidler \& Mandel (1971), as modified by Kurtzman et al. (1980), were followed.

PCR fingerprinting. Cultures grown on MYP agar were suspended in $500 \mu$ l lysing buffer $(50 \mathrm{mM}$ Tris $/ \mathrm{HCl}, 250 \mathrm{mM}$ $\mathrm{NaCl}, 50 \mathrm{mM}$ EDTA, $0 \cdot 3 \%$ SDS, pH 8) and glass beads (425-600 $\mu \mathrm{m}$; Sigma) equivalent to a volume of $200 \mu 1$ were added. After being vortexed for $3 \mathrm{~min}$, the tubes were incubated for $1 \mathrm{~h}$ at $65^{\circ} \mathrm{C}$. The suspensions were then centrifuged for $30 \mathrm{~min}$ at $4^{\circ} \mathrm{C}$. Nucleic acids were precipitated during $24 \mathrm{~h}$ at $-20^{\circ} \mathrm{C}$ with a $0 \cdot 1$ vol $3 \mathrm{M}$ sodium acetate and 2 vols absolute ethanol. Finally, the DNA was washed with ethanol $(70 \%)$, vacuum-dried and then resuspended in TE $(100 \mathrm{mM}$ Tris $/ \mathrm{HCl}, \mathrm{pH} 8,100 \mathrm{mM}$ EDTA).

The primer (GTG) $)_{5}$ (Meyer et al., 1993), synthesized by Pharmacia Amersham Biotech, was used for the microsatellite-primed PCR experiments. PCR reactions were performed in $25-\mu \mathrm{l}$ reaction volumes containing $1 \times \mathrm{PCR}$ buffer (Pharmacia Amersham Biotech), $2 \mathrm{mM}$ each of dATP, dCTP, dGTP and dTTP (Promega), 0.8 $\mu \mathrm{M}$ primer, 10-15 ng genomic DNA and 1 U Taq DNA polymerase
(Pharmacia Amersham Biotech). Amplification was performed in a Uno II Thermal Cycler (Biometra) and consisted of an initial denaturation step at $95^{\circ} \mathrm{C}$ for $5 \mathrm{~min}$, followed by 40 cycles of $45 \mathrm{~s}$ at $93{ }^{\circ} \mathrm{C}, 60 \mathrm{~s}$ at $50{ }^{\circ} \mathrm{C}$ and $60 \mathrm{~s}$ at $72{ }^{\circ} \mathrm{C}$ and then a final extension step of $6 \mathrm{~min}$ at $72^{\circ} \mathrm{C}$. A negative control, in which DNA was replaced by sterile distilled water, was also included. Amplified DNA fragments were separated by electrophoresis in $1.4 \%$ agarose gel (Gibco), in $0.5 \times$ TBE (Tris/borate/EDTA) buffer at $90 \mathrm{~V}$ for $3.5 \mathrm{~h}$ and stained with ethidium bromide. On each gel, a molecular size marker was used for reference ( $\lambda$ DNA cleaved with HindIII and $\Phi X 174$ DNA cleaved with HaeIII; Pharmacia Amersham Biotech). DNA banding patterns were visualized under UV transillumination and images were obtained using a Kodak Digital Science EDA 120 system and the Kodak Digital Science 1D Image Analysis software. DNA banding patterns were analysed using the GELCOMPAR software package, version 4.1 (Applied Maths). Similarities among isolates were estimated using the Dice coefficient and the clustering was based on UPGMA.

\section{RESULTS AND DISCUSSION}

A pink yeast strain (IGC 5628), isolated by us from home-made sauerkraut, was identified (on the basis of standard yeast identification tests) as Cryptococcus ferigula. Crossing experiments performed on CMA revealed that IGC 5628 was sexually compatible with the type strain of this species. The teleomorph of Cryptococcus ferigula is described as a new species of the genus Cystofilobasidium. 


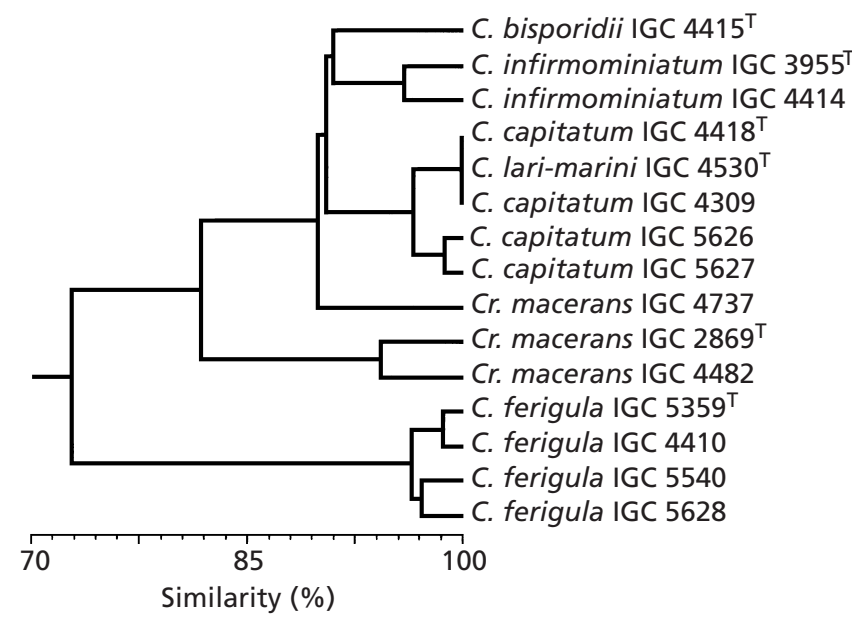

Fig. 1. Phenogram of Cystofilobasidium (C.) and Cryptococcus (Cr.) macerans based on overall similarity (simple-matching coefficient) and cluster analysis (UPGMA) of 78 physiological tests.

\section{Characterization of Cystofilobasidium ferigula sp. nov.}

A mycelium with clamp connections forms $2 \mathrm{~d}$ after inoculation, and large numbers of teliospores can be detected after 1 week at room temperature $\left(20-22^{\circ} \mathrm{C}\right)$. Germination of teliospores requires a resting period. Good results were obtained by harvesting the teliospores from 1-month-old cultures and soaking them in demineralized water for 6 weeks at $4{ }^{\circ} \mathrm{C}$. The soaked agar cubes containing the teliospores were transferred to $2 \%$ water agar and germination was observed after $2 \mathrm{~d}$ at room temperature.

Nutritional and biochemical profiles are given in Table 2. The nutritional characterization of the four strains of Cystofilobasidium ferigula corresponds to published data (Barnett et al., 1990). However, three discrepant results were found. In our study, glycerol gave negative results with most strains, citric acid was utilized by three strains and L-lysine was utilized by all strains. Moreover, of the 76 assimilation tests per-
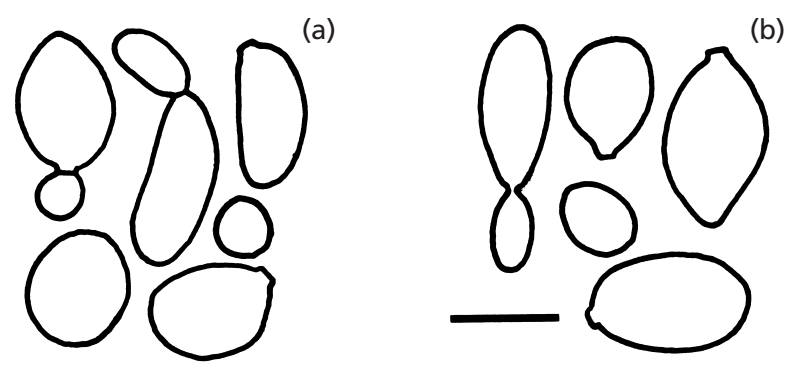

(b)

(c)

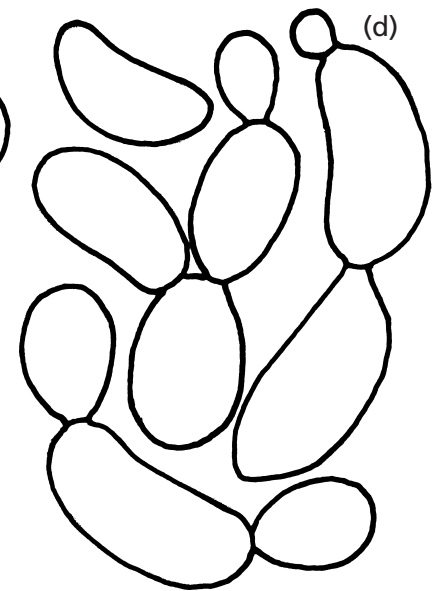

Fig. 2. Line drawings of yeast cells of Cystofilobasidium ferigula strains IGC 5359 ${ }^{\top}$ (a), IGC 4410 (b), IGC 5540 (c) and IGC 5628 (d) grown on YM agar for 1 week at $25^{\circ} \mathrm{C}$. Bar, $5 \mu \mathrm{m}$.

formed, seven gave variable results. The utilization of L-malic acid was considered variable for IGC 4410, since, in four determinations, positive results were recorded twice and negative results were also recorded twice. In spite of the discrepant results, the four strains of Cystofilobasidium ferigula formed a distinct cluster in the overall comparison of physiological data (Fig. 1).

Physiological differences relevant to the other species in the Cystofilobasidium subclade are shown in Table 3.

Micromorphological differences were found between the four Cystofilobasidium ferigula isolates (Fig. 2).

Table 3. Relevant physiological differences between the species of the subclade Cystofilobasidium

C., Cystofilobasidium.

\begin{tabular}{|c|c|c|c|c|c|c|}
\hline Characteristic & C. ferigula & C. bisporidii & C. infirmominiatum & C. capitatum & C. lari-marini & Cryptococcus macerans \\
\hline \multicolumn{7}{|l|}{ Utilization of: } \\
\hline Erythritol & - & - & - & - & - & + \\
\hline L-Malic acid & $-{ }^{*}$ & + & + & + & + & + \\
\hline L-Tartaric acid & - & - & + & - & - & - \\
\hline Ethylamine & - & + & + & + & + & + \\
\hline Cadaverine & - & + & + & + & + & + \\
\hline Growth at $30^{\circ} \mathrm{C}$ & + & - & - & - & - & - \\
\hline
\end{tabular}

* Variable for strain IGC 4410. 

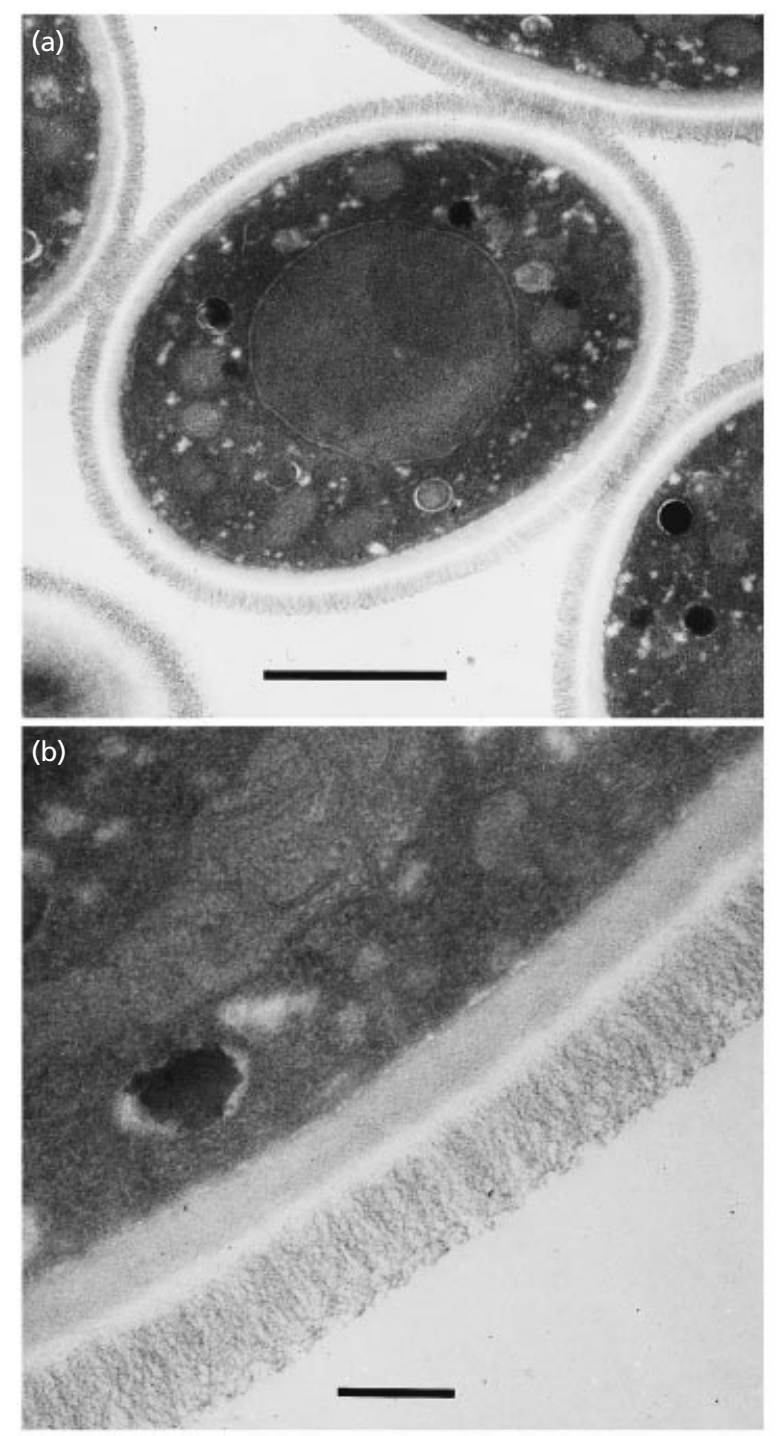

Fig. 3. Transmission electron micrographs of Cystofilobasidium ferigula (IGC $5359^{\top} \times$ IGC 5628) grown for 1 month on CMA. Note that the yeast cells have a layer of fine fibrils at the surface. Bars: $1 \mu \mathrm{m}$ (a) and $0.2 \mu \mathrm{m}$ (b).

Cells of strains belonging to mating type A1 were normally smaller than those of strain IGC 5628 (mating type A2). Moreover, cells of IGC 5628 were slightly curved. Transmission electron microscopy revealed that the yeast cells had a layer of fine fibrils at the surface (Fig. 3).

The $\mathrm{G}+\mathrm{C}$ content of the nuclear DNA of strain IGC $5359^{\mathrm{T}}$ was $67 \cdot 0 \pm 0 \cdot 40 \mathrm{~mol} \%$ (six determinations) and that of strain IGC 5628 was $66 \cdot 4 \pm 0 \cdot 12 \mathrm{~mol} \%$ (six determinations). The homology value determined in DNA-DNA reassociation experiments with the two strains ranged between 87 and $95 \%$ (three determinations).

A method of PCR fingerprinting based on the microsatellite DNA primer (GTG) $)_{5}$ was used to evaluate the relationships among Cystofilobasidium ferigula strains.

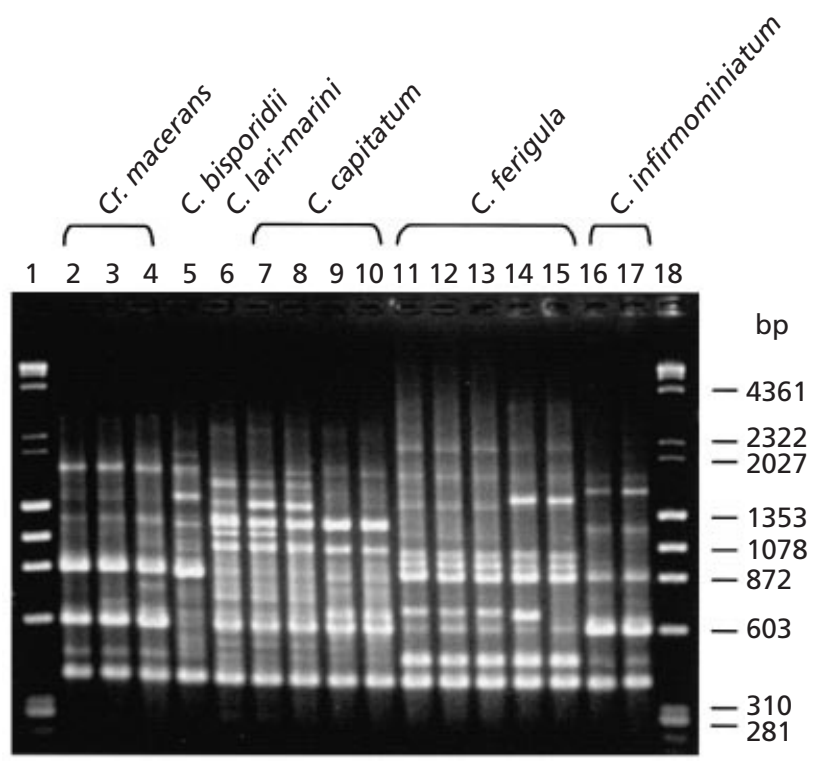

Fig. 4. Microsatellite-primed PCR fingerprints of Cystofilobasidium (C.) and Cryptococcus (Cr.) macerans obtained with primer (GTG) $)_{5}$. Lanes: 1 and 18, גDNA cleaved with HindIII/ ФX174 DNA cleaved with Haell marker; 2-4, Cryptococcus macerans IGC 2869', IGC 4482 and IGC 4737; 5, Cystofilobasidium bisporidii IGC $4415^{\mathrm{T}}$; 6 , Cystofilobasidium lari-marini IGC 4530': 7-10, Cystofilobasidium capitatum IGC $4418^{\top}$, IGC 4309; IGC 5626 and IGC 5627; 11-15, Cystofilobasidium ferigula IGC 5359', IGC 4410, IGC 4410-I, IGC 5540 and IGC 5628; 16-17, Cystofilobasidium infirmominiatum IGC $3955^{\top}$ and IGC 4414.

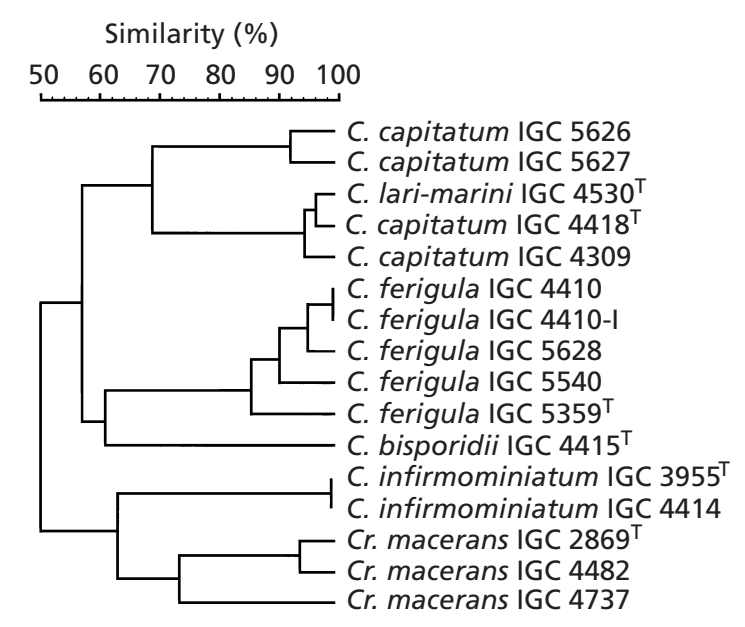

Fig. 5. Dendrogram of Cystofilobasidium species and Cryptococcus macerans based on the analysis of the PCR fingerprints obtained with primer (GTG) $)_{5}$, the Dice coefficient and the UPGMA cluster method.

Other strains belonging to the genus Cystofilobasidium and to Cryptococcus macerans were also tested using this approach. The PCR patterns obtained are depicted in Fig. 4, and their respective clustering, based on the Dice coefficient, is shown in Fig. 5. 

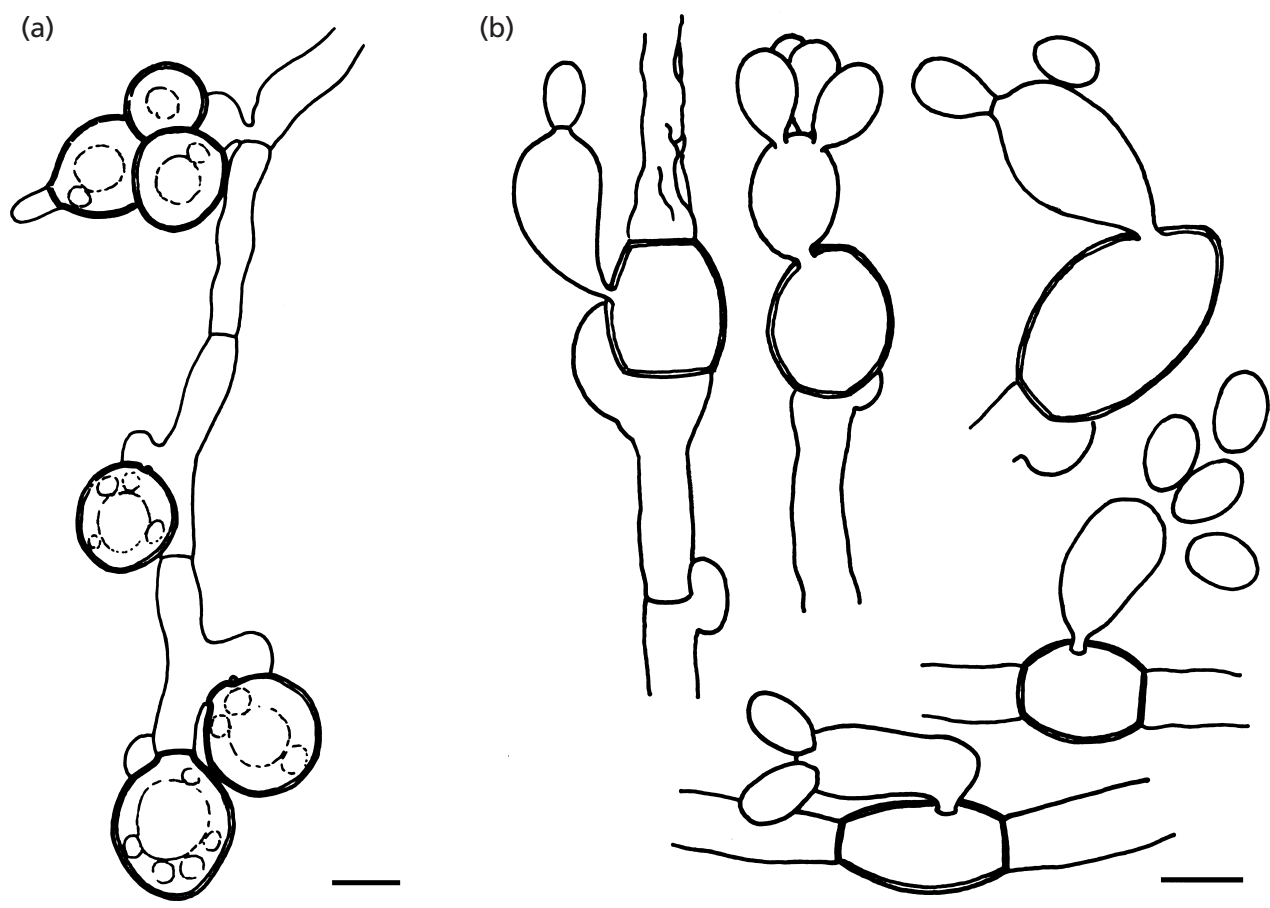

Fig. 6. Line drawings of Cystofilobasidium ferigula showing (a) a hypha with lateral and terminal teliospores (IGC 5359 $\times$ IGC 5628) after 1 month on CMA and (b) germinated teliospores with basidia and basidiospores (IGC $5359^{\top} \times$ IGC 5628 and IGC $4410 \times$ IGC 5628). Bars, $5 \mu \mathrm{m}$.

Two types of basidial morphology can be distinguished in Cystofilobasidium. In Cystofilobasidium capitatum, Cystofilobasidium bisporidii and Cystofilobasidium larimarini, the basidia are elongated. The capitate apical swelling is separated from the teliospore by a tubular structure measuring up to $80 \mu \mathrm{m}$ in Cystofilobasidium capitatum (Fell et al., 1973; Oberwinkler et al., 1983), up to $140 \mu \mathrm{m}$ in Cystofilobasidium bisporidii (Fell et al., 1973) and up to $106 \mu \mathrm{m}$ in Cystofilobasidium larimarini (Fell \& Statzell-Tallman, 1992). The other basidial type is present in Cystofilobasidium infirmominiatum and in the new species, Cystofilobasidium ferigula. In Cystofilobasidium infirmominiatum, the basidia are usually pyriform (Fig. 18 of Fell et al., 1973), with the large base attached to the teliospore, and basidial length does not exceed $14 \mu \mathrm{m}$ (Fell et al., 1973). In Cystofilobasidium ferigula, basidia are normally cylindrical and their maximum length is $12 \mu \mathrm{m}$ (Fig. 6). It has been reported that the species belonging to the first group occasionally produce short basidia, which can resemble those of the second group (Fig. 12 of Fell et al., 1973). However, the occurrence of long basidia has never been observed in Cystofilobasidium infirmominiatum or Cystofilobasidium ferigula. The short basidial type of Cystofilobasidium is similar to the basidia produced by species of Mrakia, both in shape and in size (Fig. 12 of Fell et al., 1969 and Fig. 336 of Fell \& Statzell-Tallman, 1998).
In addition to basidial morphology, other traits support the assignment of the new species to Cystofilobasidium. Cystofilobasidium ferigula and the other species in the genus assimilate inositol, glucuronate, nitrate and nitrite, possess a CoQ 8 system (Fell et al., 1999) and have xylose in the cell walls (Fell et al., 1999). Moreover, Cystofilobasidium ferigula does not utilize any of the aromatic compounds tested (Table 2). The incapacity to assimilate aromatic compounds was observed for the vast majority of species of the Cystofilobasidiales (Sampaio, 1999). The three known exceptions are Cystofilobasidium capitatum, Cystofilobasidium lari-marini and Cryptococcus huempii (Ramírez et González) Roeijmans, van Eijk et Yarrow, which were able to assimilate caffeic acid (Sampaio, 1999). Furthermore, the hyphal septa of Cystofilobasidium ferigula have dolipores without parenthesomes (Fig. 7). This septal pore type is normally interpreted as a retained primitive characteristic and is also present in Cystofilobasidium capitatum (Oberwinkler et al., 1983), Cystofilobasidium lari-marini (Suh \& Sugiyama, 1993), Cystofilobasidium infirmominiatum and Mrakia frigida (Suh et al., 1993). In Cystofilobasidium ferigula, cisternae of the endoplasmic reticulum were sometimes found in the vicinity of the septal pore (Fig. 7). In contrast to the parenthesomes, these cisternae do not have an exact position in relation to the septal pore and lack an additional internal layer. 

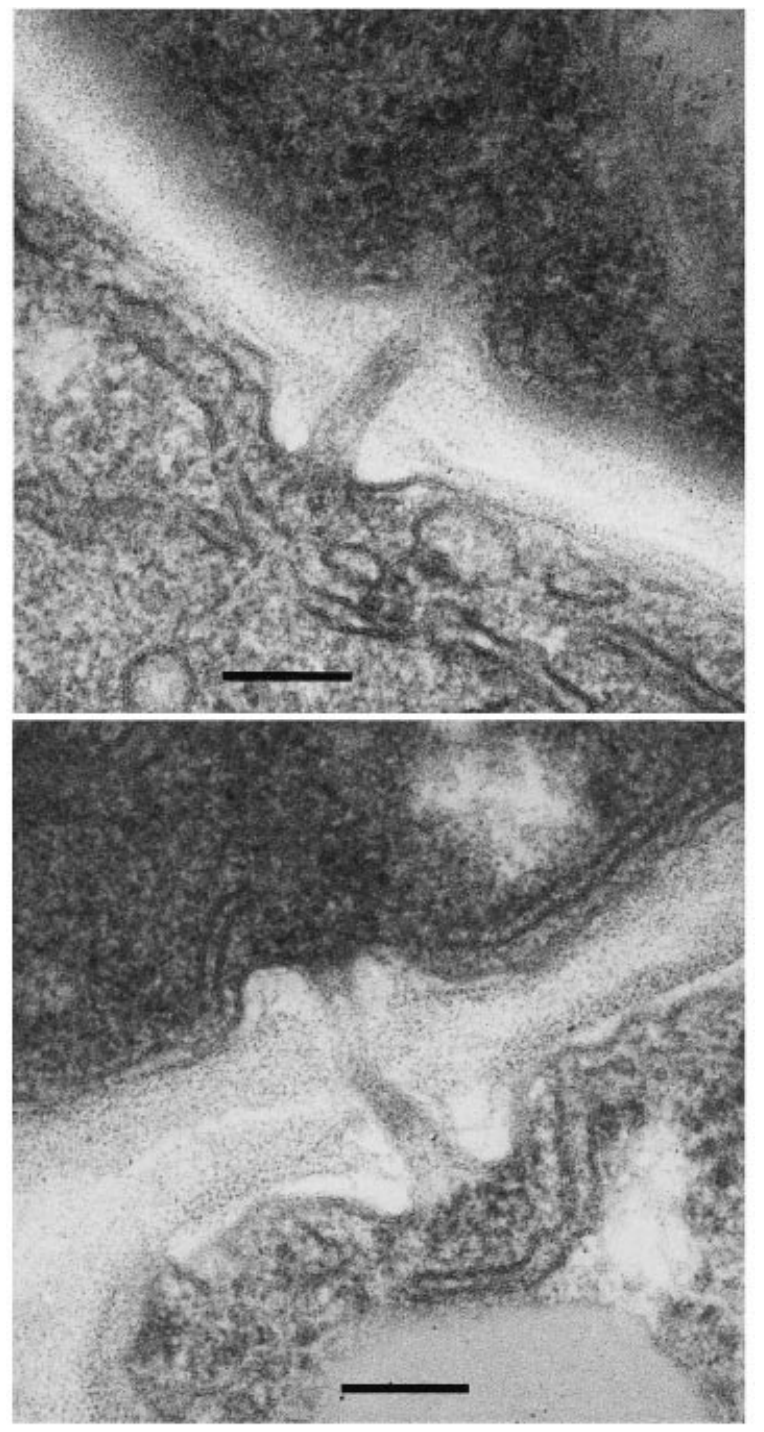

Fig. 7. Transmission electron micrographs of Cystofilobasidium ferigula (IGC $5359^{\top} \times I G C 5628$ ) grown for 1 month on CMA, showing dolipores without parenthesomes. Note that cisternae of endoplasmic reticulum are located in the neighbouring areas of the pores. Bars, $0.1 \mu \mathrm{m}$.

At the molecular level, phylogenetic studies using 26S rDNA sequences indicate a close relationship between Cystofilobasidium ferigula (Cryptococcus ferigula) and the remaining species of Cystofilobasidium (Fell et al., 1999).

The microsatellite-primed PCR fingerprinting method using primer $(\mathrm{GTG})_{5}$ proved to be a useful approach for differentiating most species of Cystofilobasidium (Figs 4 and 5). Moreover, the three strains of Cryptococcus macerans were grouped in one cluster (Fig. 5), which contradicts the heterogeneity of the species suggested in the analysis of phenotypic data (Fig. 1). During this study, a non-pigmented variant of strain Cystofilobasidium ferigula IGC 4410 was detected, purified and maintained as IGC 4410-I. The PCR-
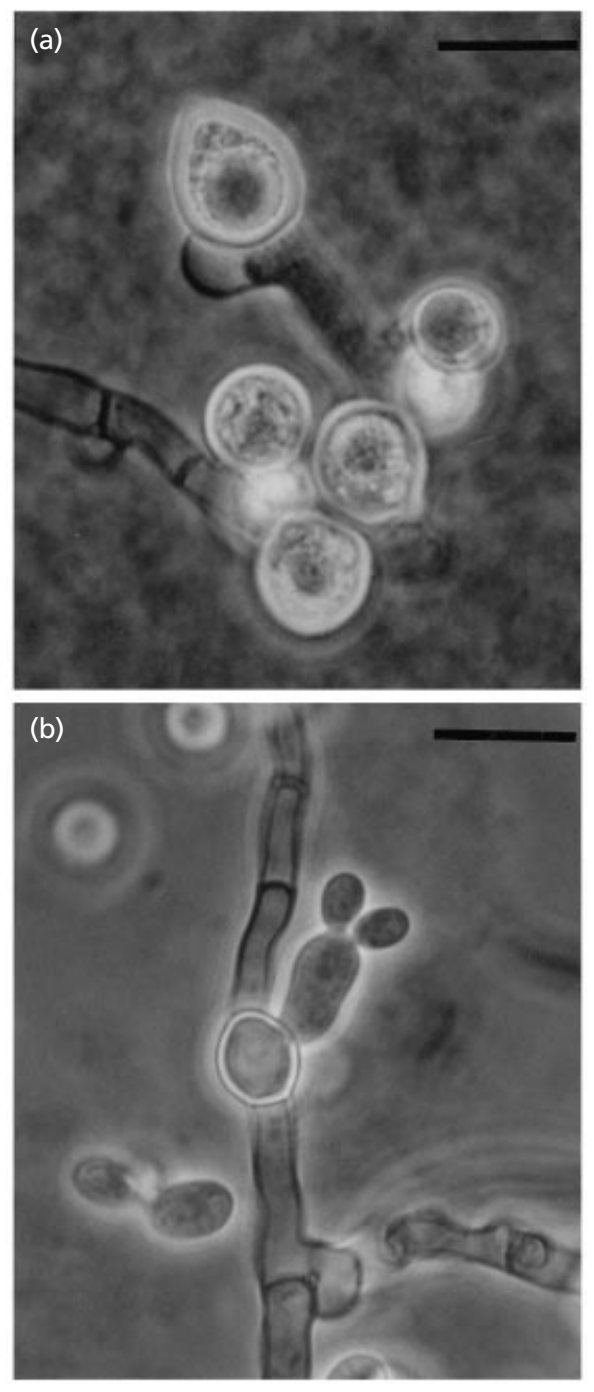

Fig. 8. Micrographs of Cystofilobasidium ferigula showing (a) 2-week-old teliospores on CMA (IGC $5359^{\top} \times$ IGC 5628) and (b) a germinated teliospore with a basidium and two basidiospores (IGC $4410 \times$ IGC 5628). Bars, $10 \mu \mathrm{m}$.

fingerprinting banding profiles validated the origin of IGC 4410-I as a non-pigmented variant of IGC 4410 (Fig. 4). Moreover, this non-pigmented variant was also sexually compatible with IGC 5628. The exception to the good species separation was Cystofilobasidium lari-marini, which clustered among the strains of Cystofilobasidium capitatum (Fig. 5). In addition, the banding profile of Cystofilobasidium lari-marini was identical to the pattern obtained for the type strain of Cystofilobasidium capitatum (Fig. 4). These results suggested conspecificity between the two species; in order to test this hypothesis, the $\mathrm{G}+\mathrm{C}$ content of the nuclear DNA was determined and DNA-DNA reassociation experiments were carried out using both type strains. Cystofilobasidium capitatum had a $\mathrm{G}+\mathrm{C}$ content of $60 \cdot 0 \pm 0 \cdot 61 \mathrm{~mol} \%$ (five determinations) and Cystofilobasidium lari-marini had a value of $60 \cdot 2 \pm$ $0.33 \mathrm{~mol} \%$ (five determinations). The homology 
values obtained ranged between 85 and $100 \%$ (three determinations), which confirms that Cystofilobasidium lari-marini must be regarded as a synonym of Cystofilobasidium capitatum.

In spite of different culture pigmentation, a close relationship had been observed between Cystofilobasidium capitatum and Cystofilobasidium lari-marini in molecular phylogenetic studies using 26S rDNA sequences (Fell et al., 1999). Moreover, Cystofilobasidium capitatum and Cystofilobasidium lari-marini are also very similar with respect to basidial morphology (Fell \& Statzell-Tallman, 1992), septal pore ultrastructure (Suh \& Sugiyama, 1993) and nutritional profiles (Table 3 and Fig. 1). Culture pigmentation must therefore be considered to be variable in Cystofilobasidium capitatum, since typical isolates of this species are orange in colour, whereas IGC 4530 has cream-coloured colonies. Pigmented yeast species can sometimes give rise to colourless variants, as was reported for Rhodosporidium toruloides Banno (Joo et $a l ., 1988)$ and as observed in the present study with strain IGC 4410-I of Cystofilobasidium ferigula.

\section{Latin diagnosis of Cystofilobasidium ferigula Sampaio, Gadanho et Bauer sp. nov.}

Hyphae hyalinae $(3-3.5 \mu \mathrm{m}$ in diametro), septis fibulatis. Teliosporae laterales, terminales vel intercalares, fibulatae, in culturis duorum mensium subglobosae ad plus minusve dacryoideae, 7-11 $\times 7-12 \mu \mathrm{m}$ si terminales vel laterales, elongatiores $(6-8 \times 8-13 \mu \mathrm{m})$ si intercalares, aggregatae demum cinnamomeae, basidiis ovoideis ad cylindraceis $(4-7 \times 7-12 \mu \mathrm{m})$ germinant. Basidiosporae sessiles, plerumque in parte apicali basidii oriuntur, gemmis germinant.

Typus depositus in collectionis Portuguese Yeast Culture Collection, FCT-UNL, Caparica, Lusitania $\left(\right.$ IGC $\left.5359^{\mathrm{T}}\right)$.

\section{Description of Cystofilobasidium ferigula Sampaio, Gadanho et Bauer sp. nov.}

Anamorphic stage: Cryptococcus ferigula (nom. corrig.) Saëz et Rodrigues de Miranda 1988 (spelled incorrectly in the original publication as Cryptococcus feraegula).

Hyphae hyaline (3-3.5 $\mu \mathrm{m}$ in diameter), with clamp connections. Teliospores lateral, terminal or intercalary on the mycelium and subtended by a clamp connection. Teliospores in 1-month-old cultures are subglobose to slightly dacryoid (Figs 6a and 8a), $7-11 \times 7-12 \mu \mathrm{m}$ when terminal or lateral, more elongated $(6-8 \times 8-13 \mu \mathrm{m})$ when intercalary, formed in large groups that become orange-brown in colour. Upon germination, teliospores originate ovoidal to cylindrical basidia $(4-7 \times 7-12 \mu \mathrm{m})$ (Figs $6 \mathrm{~b}$ and $8 \mathrm{~b})$. One to four sessile subglobose basidiospores (3-3.5 $\times 4-5 \mu \mathrm{m})$ are formed, normally on the apical portion of the basidia (Fig. 6). Basidiospores germinate by budding.
The type strain of Cystofilobasidium ferigula, strain IGC $5359^{\mathrm{T}}$ (mating type A1), has been deposited in the Portuguese Yeast Culture Collection, FCT-UNL, Caparica, Portugal.

\section{ACKNOWLEDGEMENTS}

This work was supported financially by grant PRAXIS/ PCNA/C/BIA/174/96 (FCT, Portugal) and by the Deutsche Forschungsgemeinschaft. M. G. was supported by grant PRAXIS/BTI/16804/98. The authors are indebted to Professors Isabel Spencer-Martins and Jack Fell, for critical reading of the manuscript, and to Dr Michael Weiß for preparing the Latin diagnosis.

\section{REFERENCES}

Barnett, J. A., Payne, R. W. \& Yarrow, D. (1990). Yeasts: Characteristics and Identification, 2nd edn. Cambridge: Cambridge University Press.

Britten, R. J., Pavich, M. \& Smith, J. (1970). A new method of DNA purification. Carnegie Inst Wash Year Book 68, 400-402.

Fell, J. W. \& Statzell-Tallman, A. (1992). Systematic placement of the basidiomycetous yeast Cystofilobasidium lari-marini comb. nov. as predicted by rRNA nucleotide sequence analysis. Antonie Leeuwenhoek 62, 209-213.

Fell, J. W. \& Statzell-Tallman, A. (1998). Mrakia Y. Yamada \& Komagata. In The Yeasts, a Taxonomic Study, 4th edn, pp. 676-677. Edited by C. P. Kurtzman \& J. W. Fell. Amsterdam: Elsevier.

Fell, J. W., Statzell, A. C., Hunter, I. L. \& Phaff, H. J. (1969). Leucosporidium gen. n., the heterobasidiomycetous stage of several yeasts of the genus Candida. Antonie Leeuwenhoek 35, 433-462.

Fell, J. W., Hunter, I. L. \& Tallman, A. S. (1973). Marine basidiomycetous yeasts (Rhodosporidium spp. n.) with tetrapolar and multiple allelic bipolar mating systems. Can J Microbiol 19, 643-657.

Fell, J. W., Roeijmans, H. \& Boekhout, T. (1999). Cystofilobasidiales, a new order of basidiomycetous yeasts. Int $J$ Syst Bacteriol 49, 907-913.

Fonseca, A. (1992). Utilization of tartaric acid and related compounds by yeasts: taxonomic implications. Can J Microbiol 38, 1242-1251.

Hamamoto, M., Sugiyama, J. \& Komagata, K. (1988). Transfer of Rhodosporidium infirmominiatum to the genus Cystofilobasidium as Cystofilobasidium infirmominiatum comb. nov. J Gen Appl Microbiol 34, 271-278.

Joo, W. H., Sugiyama, J. \& Komagata, K. (1988). A colorless variant derived from Rhodosporidium toruloides strain YK 212 (IAM 13509, IFO 1236) and its taxonomic implication. J Gen Appl Microbiol 34, 387-390.

Kurtzman, C. P., Smiley, M. J., Johnson, C. J., Wickerham, L. J. \& Fuson, G. B. (1980). Two new and closely related heterothallic species, Pichia amylophila and Pichia mississippiensis: characterization by hybridization and deoxyribonucleic acid reassociation. Int J Syst Bacteriol 30, 208-216.

Marmur, J. \& Doty, P. (1962). Determination of the base composition of DNA from its thermal denaturation temperature. J Mol Biol 5, 109-118.

Meyer, W., Mitchell, T. G., Freedman, E. Z. \& Vilgalys, R. (1993). Hybridization probes for conventional DNA fingerprinting used as single primers in the polymerase chain reaction to 
distinguish strains of Cryptococcus neoformans. J Clin Microbiol 31, 2274-2280.

Oberwinkler, F., Bandoni, R., Blanz, P. \& Kisimova-Horovitz, L. (1983). Cystofilobasidium: a new genus in the Filobasidiaceae. Syst Appl Microbiol 4, 114-122.

Reynolds, E. S. (1963). The use of lead citrate at high $\mathrm{pH}$ as an electron opaque stain in electron microscopy. J Cell Biol 17, 208-212.

Rolf, F. J. (1998). NTSYS-pc. Numerical Taxonomy and Multivariate Analysis System, version 2.0. New York: Applied Biostatistics.

Saëz, H. \& Rodrigues de Miranda, L. (1988). Deux nouvelles espèces de levure, d'origine animale, isolées au Parc Zoologique de Paris: Cryptococcus feraegula et Candida nanaspora. Bull Soc Mycol France 104, 213-215.

Sampaio, J. P. (1994). Utilization of low molecular weight ligninrelated aromatic compounds for the selective isolation of yeasts: Rhodotorula vanillica, a new basidiomycetous yeast species. Syst Appl Microbiol 17, 613-619.

Sampaio, J. P. (1999). Utilization of low molecular weight aromatic compounds by heterobasidiomycetous yeasts: taxonomic implications. Can J Microbiol 45, 491-512.
Sampaio, J. P. \& Fonseca, A. (1995). Physiological aspects in the systematics of heterobasidiomycetous yeasts. Stud Mycol 38, 29-46.

Seidler, R. J. \& Mandel, M. (1971). Quantitative aspects of deoxyribonucleic acid renaturation: base composition, site of chromosome replication, and polynucleotide homologies. $J$ Bacteriol 106, 608-614.

Sneath, P. H. A. \& Sokal, R. R. (1973). Numerical Taxonomy. San Francisco: W. H. Freeman.

Spurr, A. R. (1969). A low-viscosity epoxy resin embedding medium for electron microscopy. J Ultrastruct Res 26, 31-43.

Suh, S.-O. \& Sugiyama, J. (1993). Septal pore ultrastructure of Leucosporidium lari-marini, a basidiomycetous yeast, and its taxonomic implications. J Gen Appl Microbiol 39, 257-260.

Suh, S.-O., Hirata, A., Sugiyama, J. \& Komagata, K. (1993). Septal ultrastructure of basidiomycetous yeasts and their taxonomic implications with observations on the ultrastructure of Erythrobasidium hasegawianum and Sympodiomycopsis paphiopedili. Mycologia 85, 30-37.

Yarrow, D. (1998). Methods for the isolation, maintenance and identification of yeasts. In The Yeasts, a Taxonomic Study, 4th edn, pp. 77-100. Edited by C. P. Kurtzman \& J. W. Fell. Amsterdam: Elsevier. 